\title{
In-Silico Analysis of Methoxyl Pectin Compounds from Banana Peels as HMG- CoA Reductase Inhibitor Complexes
}

\author{
Adelia Adrianne Tapiory ${ }^{1,2}$, Kadita Octavia Pertiwi ${ }^{1,2}$, Khalisa Fadilla ${ }^{1}$, Davy Reyhanditya ${ }^{1,2}$, \\ Fatchiyah Fatchiyah ${ }^{1,2^{*}}$ \\ ${ }^{1}$ Biology Department, Faculty Mathematics and Natural Sciences, Brawijaya University \\ Jl. Veteran, No 1, Malang, 65145, Indonesia \\ ${ }^{2}$ Research Center for Smart Molecules of Natural Genetic Resources (SMONAGENES) \\ Brawijaya University, Malang, 65145, Indonesia
}

Submission: April 2020; Revised: May 2020; Accepted: May 2020

*Corresponding author:Fatchiyah Fatchiyah; e-mail: fatchiya@ub.ac.id; tel.: +62-341-575841

\begin{abstract}
Cardiovascular disease (CVD) is one of the most important health problems that emerge in the last decade. The major factor of the disease is by the high level of cholesterol in blood. Several ways can be used to reduce the amount of cholesterol in blood, as using HMGR treatment. This enzyme acts as catalyst in the initial step and limits the cholesterol biosynthesis. Pectin is a polysaccharide compound that used as an agent to reduce the total cholesterol in bloods. In this research, we aim to analyze the function of methoxyl pectin in inhibiting excessive cholesterols in blood by binding with the HMGR. The method we used in this research, first step searching data mining from database and preparation of protein and ligands using discovery studio. Molecular docking analyzed via HEX software. The result of molecular docking is visualized using discovery studio to analyze the energy binding level, also the bonds that formed and the impact that comes from the bonds. The results show that HMGR binding energy for native ligand (HMGCoA) as control ligand was $-450.2 \mathrm{~kJ} / \mathrm{mol}$, methoxyl pectin was $-177.3 \mathrm{~kJ} / \mathrm{mol}$ and atorvastatin, a group of drugs commonly used for CVD treatment was $-386.6 \mathrm{~kJ} / \mathrm{mol}$. HMGR binds to HMGCoA with 7 hydrogen bonds and a hydrophobic bond. Methoxyl pectin binds to HMGR with residue Glu700 and His625. Atorvastatin binds to HMGR with residue Lys633 and Leu634. It is known that native ligands bind to HMGR when cholesterol goes down. Based on research, methoxyl pectin bond with HMGR is the same as the HMGCoA native ligand with HMGR, namely His635. This shows that methoxyl pectin is predicted to inhibit HMGR and resulting LDL cholesterol decrease. Methoxyl pectin is indicated to be an alternative drug for cardiovascular disease considering that atorvastatin has several side effects. Methoxyl pectin is derived from natural ingredients with minimum side effect.
\end{abstract}

Keywords: atorvastatin, binding energy, cardiovascular disease, HMGR, methoxyl pectin

\section{INTRODUCTION}

Cardiovascular disease or CVD is a disease that becomes the important health problem in the Asia Pacific region. Emergence of this disease including rapid urbanization, disorganized dietary habit, high level of smoking rates, and reduced physical activity. In 2008, 17.3 billion people are predicted died because of CVD, including $30 \%$ of the population. Some of researcher already predicted that, in 2030 this disease would take lives up to 23.4 billion people, including $35 \%$ of the population in the world. Cholesterol is the main factor of this disease and furthermore will impact the heart. High level of cholesterols has higher risks, including coronary heart and stroke [1].

Scientists have been studied this disease and the main reason is to find the cure for this disease. Many studies examined the methods to reduce cholesterol levels throughout the treatment within the HMGCoA-Reductase. This enzyme is regulated at transcription level and post-transcription level. High level of cholesterols is caused by some of factors, including reduction in the transcription process of the HMGR genes and leading to the reduction of HMGR mRNA [2]. Transcription regulation is controlled by SREBP protein, which forms a complex in the endoplasmic reticulum membrane with Scap protein that acts as an integral protein. High levels of cholesterol in cell, the SREBP-Scap complex is located on the RE membrane. When the level of cholesterol is lower, the complex will be transported to the Golgi apparatus in COPII vesicle. SREBP is activated by protolithic activity which breakdown the NH2 terminal domain on the membrane, which HMGR will activate its transcription [3].

Pectin is a polysaccharide compounds, usually contained in plants. Some of scientist believes that pectin can be used to reduce total of cholesterol, including LDL, apolipoprotein A, and apolipoprotein B. [4]. Pectin can be found in banana flesh and banana 
peel [5]. In this work, analysis of in silico was carried out on the compound of methoxyl pectin to prevent the excessive production of cholesterol. We used pectin from banana peels and we hope that pectin from this banana peels can be used as an alternative medicine to reduce excess LDL cholesterol in blood.

\section{METHODS}

\section{Data Mining}

HMG-CoA Reductase structure was downloaded from RCSB PDB (www.rcsb.org) as PDB format, whereas the ligands structure were downloaded from PubChem (www.pubchem.ncbi.nlm.nih.gov) as SDF format, included Methoxyl Pectin, HMG CoA, and Atorvastatin. The protein and ligands used and their ID is listed in Table 1.

\section{Protein and Ligand Preparation}

HMG-CoA Reductase was prepared using Biovia Discovery Studio Visualizer 2019 software to remove water molecules and native ligands. After that, protein saved in PDB format. Ligands that have been obtained from searches using PubChem were then prepared using PyRx software to minimize energy and saved in PDB format (.pdb).

\section{Molecular Docking}

Molecular docking between protein and ligands were simulating using HEX 8.0.0 software for docking and the Shape + Electro correlation type in docking controls. The results were saved in format (.pdb) with information about the energy stored in the format (.txt).

\section{Visualization}

Protein-ligand interaction was visualized using Biovia Discovery Studio Visualizer 2019. Then, results were analyzed by determining the energy level and the binding area. In addition, the type of bonds formed and the effects of these bonds were analyzed.

Table 1. The identity of proteins and ligands

\begin{tabular}{clll}
\hline $\begin{array}{c}\text { Protein } \\
\text { Name }\end{array}$ & PDB ID & Ligand Name & PubChem ID \\
\hline HMGR & IDQ8 & Methoxyl Pectin & 854 \\
& & HMG CoA & 87642 \\
& & Atorvastatin & 60823 \\
\hline
\end{tabular}

\section{RESULTS AND DISCUSSION}

\section{Native Ligand and HGMR}

Binding Energy of Native Ligand and HMGR is $-450.2 \mathrm{~kJ} / \mathrm{mol}$, shows that the interaction stronger than the interaction HMGR with atorvastatin or methoxyl pectin. Based on the interaction between HMGR with native ligand (HMG-CoA) as control, there are 7 hydrogen bonds and a hydrophobic bond (Figure 1).

The analysis results show that the validation process carried out from the docking results has several parameters such as binding energy, inhibition constants, and amino acid bonds. The binding energy value of methoxyl pectin and HMGR complex compound is $-177.3 \mathrm{~kJ} / \mathrm{mol}$ (Table 2). This binding energy value can affects the dissociation constant of the phenolic hydroxyl group so that the molecule is hydrophobic. Lipophilic or non-polar compounds will more easily penetrate the membrane because the similarity of lipophilicity with the lipid phase [6]. The bonds formed between the methoxyl pectin compound and HMGR are shown in the Table 2, which shows that there are 2 amino acid residues that interact and forming hydrogen bonds. They are His635 and Glu700 (Figure 2).

\section{Methoxyl Pectin and HGMR}

His635 forms hydrogen bonds with carbon hydrogen bonds types and Glu700, which forms hydrogen bonds with conventional hydrogen bond types. Based on the bonds formed, the interaction between the methoxyl pectin compound and HMGR is on the active site, ligands are said to be on the active site of HMGR if the amino acid residue bonds are formed E (glutamic acid), D (aspartic acid), and K (lysine) [7]. The amino acid His635 binds to the active site of the small domain and Glu700 binds to the active site of the large domain, where the active site of the small domain consists of amino acid residues 592-582, while the large domain consists of amino acid residues 694-872 [8].

\section{Atorvastatin and HGMR}

The analysis result between HMGR and Atorvastatin (Figure 3) which is one of the statin drugs group showed an interaction and formed a bond, with the binding energy value of the complex compound atorvastatin and HMGR is $-386.6 \mathrm{~kJ} / \mathrm{mol}$ (Table 2). This interaction occurs between domains $\mathrm{A}$ and $\mathrm{D}$ of the HMGR protein. The bonds formed between the atorvastatin compounds and HMGR are shown in the Table 2 that shows that there are 2 amino acid residues that interact and forming hydrogen bonds. The two amino acid residues are Leu634 and Lis633. Leu634 forms hydrogen bonds with conventional hydrogen bonds types and Lis633, which form hydrophobic, bonds with Pi-Alkyl types. Based on literature, the amino acid sequence numbers 633 and 634 are in the S-terminal (small) domain. It is known that the active site location of HMGR is between the S (small) and L (large) domains [8]. 

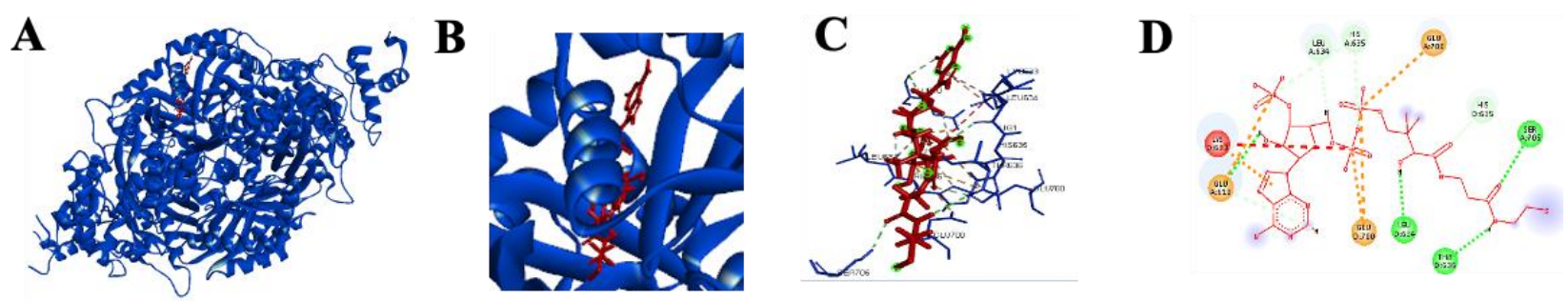

Figure 1. Docking result between native ligand (HMG-CoA): A) overall interaction; B) with magnification; C) methoxyl pectin ligand; and D) 2D structure (energy $=-450.2 \mathrm{~kJ} / \mathrm{mol}$ ).
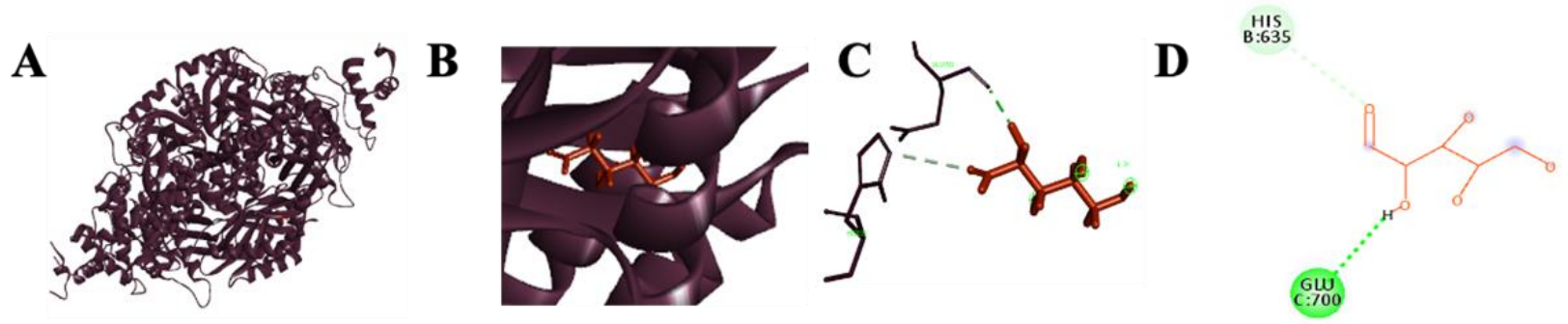

Figure 2. Docking result between methoxyl pectin and HMGR: A) overall interaction; B) with magnification; C) methoxyl pectin ligand; and D) 2D structure (energy $=-177.3 \mathrm{~kJ} / \mathrm{mol}$ ).

$\mathbf{A}$

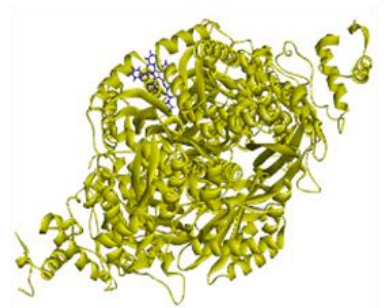

B

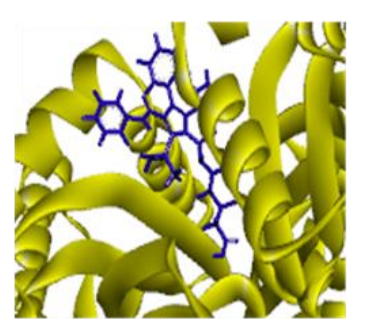

C

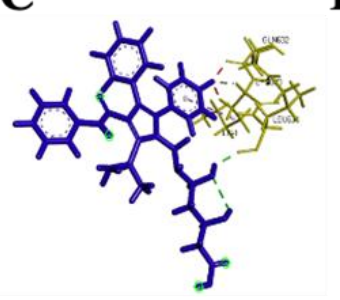

D

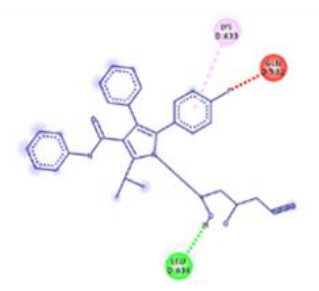

Figure 3. Docking result between atorvastatin and HMGR: A) overall interaction; B) with magnification; C) atorvastatin ligand; and D) 2D structure (energy: $-386.6 \mathrm{~kJ} / \mathrm{mol}$ ).

Based on its structure, it is known that the methoxyl pectin compound does not have a benzene group such as HMG-CoA while the Atorvastatin has a benzene group such as HMG COA [9], produces a stronger bond characterized by its binding energy of $-386.6 \mathrm{~kJ} / \mathrm{mol}$. Methoxyl pectin compounds generally contain more carboxyl groups [10]. Pectin showed no post-consumptive side effects in the research conducted. No statistically significant differences were observed for headache, nausea, stomach bloating, diarrhea, constipation, stomach complaint before after consumption [11].

Based on Table 2, it shows that the native ligand (HMGCoA) binds to HMGR protein with hydrogen bond type and the residue are Ser705, Glu610, Leu634, Thr636, and His635 also hydrophobic bond type with residue Lys633. Methoxyl pectin binds to HMGR protein with hydrogen bond type and the residue are Glu 700 with conventional hydrogen bond and His635 with carbon hydrogen bond. Interaction between HMGR and atovastatin involved 2 amino acid residues Leu634 and Lys633. Leu634 forms hydrogen bonds with conventional hydrogen bonds types and Lys633 form hydrophobic bonds with Pi-
Alkyl types. Atorvastatin and native ligand as control, has two same interacted residues with the same type of interaction. While, methoxyl pectin and native ligand has one same interacted residue with the same type of interaction namely His635, it is hydrogen bond with carbon hydrogen bond type [7].

The result shows that interaction between Atorvastatin and HMGR stronger than methoxyl pectin and HMGR (Figure 5). On the other hand, Atorvastatin is synthetic compounds that cause several side effects to the patient, while methoxyl pectin as derived from natural ingredient did not cause any side effects, metabolites of atorvastatin agents have anti-HMG-CoA reductase properties. Although the interaction between pectin and HMGR is less good compared to the interaction of atorvastatin with HMGR, however pectin can be used as an alternative drug with minimal side effects $[11,13,14]$.

Based on Ramachandran plot for HMGR protein, percentage of favored region is $95.4 \%$, allowed region is $3.8 \%$, and outlier region is $0.7 \%$. Based on this percentage, it shows that HMGR protein has a decent structure because this protein has high percentage of 
Tapiory, A.A., Pertiwi, K.O., Fadilla, K., Reyhanditya, D., Fatchiyah, F. - In Silico Analysis of Methoxyl Pectin Compound from

favored region. A suitable structure is characterized by favored region percentage that exceeds $50 \%$. High percentage of amino acid residue in favoured region indicates better quality of the structure [12].

Table 2. Interacted residues and the number of interaction formed by HMGR complexes with their respective ligands used in this study.

\begin{tabular}{|c|c|c|c|c|c|c|c|}
\hline Interaction & $\begin{array}{l}\text { Interaction } \\
\text { Point }\end{array}$ & $\begin{array}{l}\text { Distance } \\
\text { (A) }\end{array}$ & $\begin{array}{c}\text { From } \\
\text { Chemistry }\end{array}$ & $\begin{array}{c}\text { To } \\
\text { Chemistry }\end{array}$ & Type & $\begin{array}{l}\text { Chemistry } \\
\text { Bond }\end{array}$ & $\begin{array}{c}\text { Energy } \\
\text { Binding } \\
(\mathrm{kJ} / \mathrm{mol})\end{array}$ \\
\hline \multirow{7}{*}{$\begin{array}{l}\text { HMGCoA } \\
\text { (Native } \\
\text { Ligand) }\end{array}$} & $\begin{array}{l}\text { A:SER705:HG - } \\
\text { :LIG1:O }\end{array}$ & 2,43 & H-Donor & H-Acceptor & $\begin{array}{l}\text { Conventional } \\
\text { Hydrogen Bond }\end{array}$ & Hydrogen Bond & \multirow{7}{*}{-450.2} \\
\hline & $\begin{array}{c}\text { :LIG1:H - } \\
\text { A:GLU610:O }\end{array}$ & 2,85 & H-Donor & H-Acceptor & $\begin{array}{l}\text { Conventional } \\
\text { Hydrogen Bond }\end{array}$ & Hydrogen Bond & \\
\hline & $\begin{array}{c}\text { :LIG1:H - } \\
\text { D:LEU634:O }\end{array}$ & 2,61 & H-Donor & H-Acceptor & $\begin{array}{l}\text { Conventional } \\
\text { Hydrogen Bond }\end{array}$ & Hydrogen Bond & \\
\hline & $\begin{array}{c}\text { :LIG1:H - } \\
\text { D:THR636:O }\end{array}$ & 2,65 & H-Donor & H-Acceptor & $\begin{array}{l}\text { Conventional } \\
\text { Hydrogen Bond }\end{array}$ & Hydrogen Bond & \\
\hline & $\begin{array}{l}\text { A:HIS635:CA - } \\
\text { :LIG1:O }\end{array}$ & 3,66 & H-Donor & H-Acceptor & $\begin{array}{c}\text { Carbon } \\
\text { Hydrogen Bond }\end{array}$ & Hydrogen Bond & \\
\hline & $\begin{array}{c}\text { :LIG1:H - } \\
\text { A:LEU634:O }\end{array}$ & 2,30 & H-Donor & H-Acceptor & $\begin{array}{c}\text { Carbon } \\
\text { Hydrogen Bond }\end{array}$ & Hydrogen Bond & \\
\hline & $\begin{array}{c}\text { :LIG1 - } \\
\text { D:LYS633 }\end{array}$ & 5,40 & Pi-Orbitals & Alkyl & Pi-Alkyl & $\begin{array}{l}\text { Hydrophobic } \\
\text { Bond }\end{array}$ & \\
\hline \multirow{2}{*}{$\begin{array}{c}\text { HMGR + } \\
\text { Methoxyl } \\
\text { Pectin }\end{array}$} & $\begin{array}{c}\text { :LIG1:H - } \\
\text { C:GLU700:O }\end{array}$ & 2,10 & H-Donor & H-Acceptor & $\begin{array}{l}\text { Conventional } \\
\text { Hydrogen Bond }\end{array}$ & Hydrogen Bond & \multirow{2}{*}{-177.3} \\
\hline & $\begin{array}{l}\text { B:HIS635:CE1 - } \\
\text { :LIG1:O }\end{array}$ & 3,78 & H-Donor & H-Acceptor & $\begin{array}{c}\text { Carbon } \\
\text { Hydrogen Bond }\end{array}$ & Hydrogen Bond & \\
\hline \multirow{2}{*}{$\begin{array}{l}\text { HMGR + } \\
\text { Atorvastatin }\end{array}$} & $\begin{array}{c}\text { :LIG1:H - } \\
\text { D:LEU634:O }\end{array}$ & 1,84 & H-Donor & H-Acceptor & $\begin{array}{l}\text { Conventional } \\
\text { Hydrogen Bond }\end{array}$ & Hydrogen Bond & \multirow{2}{*}{-386.6} \\
\hline & $\begin{array}{c}\text { :LIG1- } \\
\text { D:LYS633 }\end{array}$ & 4,78 & Pi-Orbitals & Alkyl & Pi-Alkyl & $\begin{array}{l}\text { Hydrophobic } \\
\text { Bond }\end{array}$ & \\
\hline
\end{tabular}

$\mathbf{A}$

\section{CONCLUSION}

Native ligand binds to HMGR when cholesterol goes down. Based on the current research, it is suggested that the methoxyl pectin bond with HMGR is the same as the HMGCoA native ligand with HMGR, namely His635. This shows that methoxyl

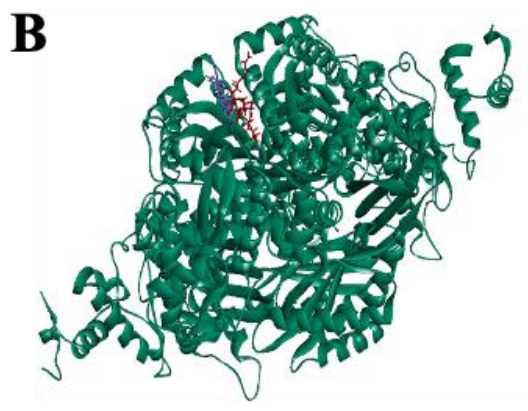

Figure 4. Docking result between HMGR-CoA complex with: A) methoxyl pectin; B) atorvastatin.

pectin is predicted to inhibit HMGR because of the formation of the same bonds with native ligand to HMGR. In the previous study has shown that uses of methoxyl pectin in enriched semi-synthetic diet known to reduces the total of cholesterol and tryglyceride plasma. Because of the reduction of total cholesterol, the LDL rasio tend to decrease, followed by pectin administration. 


\section{ACKNOWLEDGEMENT}

We send our regards to our research center of, SMONAGENES, also to bioinformatics lecturers for helping us to finish this research.

\section{REFERENCES}

1. Wadhera, R. K., M. D. Mphil, D. L. Steen. 2016. A review of low-density lipoprotein cholesterol, treatment strategies, and its impact on cardiovascular disease morbidity and mortality. Journal of Clinical Lipidology. 2016(10): 472489

2. Bradshaw, R \& P. Stahl. 2015. Encyclopedia of Cell Biology. Academic Press: USA.

3. Burg, J. S. Espenshade, P. J. 2011. Regulation of HMG-CoA reductase in mammals and yeast. Progress in lipid research. 50(4): 403-410.

4. Nurman, Z., Masrul, S. Sastri. 2017. Pengaruh Pektin Buah Apel (Malus Sylvestris Mill) Terhadap Kadar LDL Kolesterol pada Tikus Putih Jantan (Rattus Novergicus) Hiperkolesterolemia. Jurnal Kesehatan Andalas, 6(3): 679-684.

5. Cho, S. S., \& Samuel, P. (Eds.). 2009. Fiber ingredients: food applications and health benefits. CRC press: USA.

6. Sulastri. S., H. Riza., \& I. Fajriaty. 2018. Studi In Silico Senyawa Turunan Flavonoid terhadap Enzim HMGCoA Reduktase. Fakultas Kedokteran Universitas Tanjungpura. Kalimantan Barat.
7. Istvan, E. S., M. Palnitkar., S. K. Buchanan., \& J. Deisenhofer. 2000. Crystal structure of the catalytic portion of human HMG-CoA reductase: insights into regulation of activity and catalysis. The embo journal 19(5): 819-830.

8. Lin, S. H., Huang, K. J., Weng, C. F., \& Shiuan, D. 2015. Exploration of natural product ingredients as inhibitors of human HMG-CoA reductase through structure-based virtual screening. Drug design, development and therapy. 9: 3313.

9. McMurry, J. 2012. Organic Chemistry. Cengage. Canada.

10. Sundar Raj, A. A., Rubila, S., Jayabalan, R., \& Ranganathan, T. V. 2012. A review on pectin: Chemistry due to general properties of pectin and its pharmaceutical uses. Scientific reports. 1: 550-551.

11. Brouns, F., E. Theuwissen., A. Adam., M. Bell., A. Berger., \& R. P. Mensink. 2011. Cholesterollowering properties of different pectin types in mildly hyper-cholesterolemic men and women. European journal of clinical nutrition. 66(5): 591-599.

12. Amelia, F. 2013. Modeling Struktur Protein Vaksin H5N1 HA BTB Menggunakan I-Tasser. Jurnal Sainstek Universitas Negeri Gorontalo, 7(1).

13. Main, L., \& B. Rai. 2015. 4 Steps to Lower Cholesterol: The Practical Guide to a healthy heart. Vermilion: London.

14. Evans, M. \& A. Rees. 2002. Effects of HMGCoA Reductase Inhibitors on Skeletal Muscle. Drug Safety. 25(9): 649-663. 